\title{
„Bara ekki mínar týpur!“ Sjálfsmyndarsköpun, félagsleg aðgreining og framhaldsskólaval
}

\author{
Berglind Rós Magnúsdóttir og Unnur Edda Garðarsdóttir
}

\begin{abstract}
Um höfundana $\quad$ About the authors $>$ Heimildir
Á síðustu áratugum hefur töluvert verið rætt um skólavalsstefnur, par sem árangur á afmörkuðu sviði ræður alfarið aðgengi nemenda að bóknámsbrautum í tilteknum skólum. Skólinn hefur á síðustu áratugum orðið mikilvægur liður í félags- og menningarlegri aðgreiningu milli hópa samfara auknu aðgengi að framhaldsskóla, vaxandi samkeppni og stéttaskiptingu í samfélögum. Allir geta nú sótt framhaldsskóla en ekki hvaða framhaldsskóla sem er. Í rannsókninni er byggt á hugtökum Bourdieu um samspil veruháttar, vettvangs og auðs pegar rætt er um stéttarstöðu, sjálfsmynd og aðgreiningu og hvernig val nemenda á námi til stúdentsprófs mótast af pessu samspili. Hér er sjónum beint að framhaldsskólavali bóknámsnemenda á höfuðborgarsvæðinu; hvernig peir skilgreina skólana í hinu félagslega stigveldi. Sérstök áhersla er á að skoða val og gildi nemenda með veruhátt rótgróinnar millistéttar, sem samkvæmt Bourdieu er talinn samsvara best menningu og áherslum hefðbundins bóknáms.
\end{abstract}

Tekin voru viðtöl við 19 nemendur sem töldust ná góðum árangri í sínum skóla og voru á fjórða námsári. Skólarnir fjórir voru valdir út frá háu eđa lágu höfnunarhlutfalli við inntöku nemenda á síðustu fimm árum. Ljóst er á orðum viðmælenda að skólaval er mikilvægur farvegur sjálfsmyndarsköpunar og aðgreiningar. Hjá peim sem eiga sér menntauppruna aftur í æettir kemur skýrast fram að pað er ekki aðeins vilji nemenda eða einlægur áhugi sem stýrir valinu heldur einnig brýstingur frá fjölskyldumeðlimum og óorðaðar væntingar frá samferðafólki sem eiga pátt í pessu ferli. Ástæður vals eru oft óljósar pangað til hefðbundnum valmöguleikum er ógnað. Pað er ekki fyrr en nemendur af rótgróinni millistétt fara út fyrir upprunavettvang sinn sem peir upplifa misgengi milli veruháttar og vettvangs. Meðvitund um forréttindi, félagslegan ójöfnuð og stéttastöðu er almennt takmörkuð en skapaðist hjá peim tveimur nemendum úr rótgróinni millistétt sem höfðu farið út fyrir upprunavettvang sinn.

Efnisorð: Framhaldsskóli, skólaval, nemendur, sjálfsmyndarsköpun, stétt, skóli án aðgreiningar, Bourdieu.

\section{Inngangur}

Á síðustu áratugum hefur töluvert verið rætt um skólavalsstefnur par sem árangur á afmörkuðu sviði ræður aðgengi nemenda að bóknámsbrautum í tilteknum skólum. Slíkar stefnur byggjast á verðleikaræði og síðar nýfrjálshyggju par sem litið er svo á að einstaklingurinn beri alfarið ábyrgð á möguleikum sínum og árangri á menntavettvangi (Dovemark o.fl., 2018). Lykilhugtökin sem lýsa pessari próun eru samkeppni, árangur og markaðs-, stjórnunar- og einstaklingsvæðing (Berglind Rós Magnúsdóttir, 2013; Dýrfjörð og Magnúsdóttir, 2016; Lindblad, Johannesson og 
Simola, 2002). Skólakerfið byggist á hugmyndum um verðleikaræði (e. meritocracy), p.e. að allir geti náð árangri ef peir leggja hart að sér og velja góða skóla, óháð uppruna og stéttarstöðu. Í umræðu um árangur í skólastarfi er yfirleitt ekki talað um áskipuð eða uppsöfnuð forréttindi hópa eða stofnana. Bourdieu var einn af peim fyrstu sem afbyggði pessa hugmynd um verðleikaræðið með gögnum um franskt menntakerfi og benti á að samspil sögulegra og félagslegra pátta geti opnað eða hindrað möguleika (Bourdieu, 1973; Bourdieu og Passeron, 1977).

Í rannsókninni er byggt á hugtökum Bourdieu um samspil veruháttar, vettvangs og auðs pegar rætt er um stéttarstöðu, sjálfsmynd og aðgreiningu og hvernig val nemenda á framhaldsskóla og námi til stúdentsprófs mótast af pessu samspili. Eldri félagsfræðilegar skilgreiningar á stétt byggjast að miklu leyti á formgerðarlegum breytum, p.e. stöðu einstaklinga og hópa í hinu efnahagslega stigveldi, en par koma til skjalanna pættir eins og aðgengi að framleiðslutækjum, starfsheiti og prófgráđur, svo eitthvað sé nefnt (Wright, 2005). Skilgreining Bourdieu á stétt er mun víðtækari, fangar bæði sögulega, félagslega og menningarlega pætti og tekur jafnframt til huglægra pátta, eins og stéttbundinna væntinga og áforma, auk efnislegra pátta eins og limaburðar og klæðnaðar. Dessir ólíku pættir koma saman í einstaklingnum og mynda pað sem Bourdieu kallar veruhátt (1. habitus) hans. Veruhátt má skilgreina sem nokkurs konar félagslegt innræti sem samsett er úr sögu og reynslu einstaklingsins og er hann pví nátengdur stöðu hans í hinu félagslega stigveldi. Hann gerir раð аð verkum að einstaklingurinn er eins og „fiskur í vatni“ í sínu venjubundna umhverfi, honum líður eins og hann sé ,á réttri hillu“ í lífinu. Að sama skapi skilgreinir veruháttur sjóndeildarhring pess sem á í hlut, p.e. pá möguleika sem hann upplifir innan eða utan seilingar. Dannig er ljóst að veruháttur er bæði mótaður af hinu félagslega og er mótandi afl í lífi einstaklinga og hópa (Bourdieu og Wacquant, 1992).

Veruhátturinn felur einnig í sér tiltekna sjálfsmynd, en samkvæmt Tilly (1996) má skilja sjálfssmynd sem upplifun einstaklings af félagslegri staðsetningu sinni auk virkrar táknrænnar framsetningar (e. representation) á peirri upplifun. Fræðimenn hafa reyndar fjallað á ólíkan hátt um sjálfsmyndina. Samkvæmt Foucault er sjálfsmyndin félagslegt ferli (Hall, 2001). Einstaklingurinn hefur ekki að geyma eðlislægan kjarna heldur verður sjálfið til í viðvarandi samræðu við aðra. Bourdieu lagði meiri áherslu á iðkun í pessu samhengi og taldi að sjálfsmynd einstaklingsins verði til við ítrekaða og venjubundna iðkun (e. practice) sem markast af formgerð peirra stofnana og samfélaga sem einstaklingurinn hefur verið pátttakandi í. Veruháttur hans er pví birtingarmynd pess hvar hann hefur alið manninn, með hverjum og við hvað hann hefur sýslað. Út frá pessum skilningi er ekki gert ráð fyrir að fólk búi yfir miklum möguleikum til sjálfsrýni eða til pess að breyta eða víkja frá sínum veruhætti. Kenning Bourdieu um veruhátt hefur af pessum sökum sætt gagnrýni fræðimanna fyrir að hafna möguleikanum á rökrænum eða meðvituðum áformum einstaklingsins um að „skapa sig“ á tiltekinn hátt (Conde, 2011). Bottero (2010) hefur m.a bent á að ekki sé hægt að einskorða umfjöllun um sjálfsmynd við pá ómeðvituðu sjálfsmynd sem Bourdieu talar um að spretti ósjálfrátt úr veruhættinum heldur purfi einnig að taka til greina sjálfsmynd sem táknræna „framsetningu“ (e. representation) á sjálfinu, p.e. pað mjög svo mannlega verkefni að varpa tiltekinni mynd af sér út í samfélagið í peim tilgangi að öðlast betri stjórn á félagslegri stöðu sinni og afdrifum. Loks er mikilvægt að skoða sjálfsmynd í samhengi samsömunar, p.e. hvernig táknbundin iðkun er notuð til pess að draga fólk í dilka, til pess að mynda og kyrrsetja afmarkaða hópa á grundvelli sameiginlegra tilhneiginga (e. dispositions). Einstaklingar purfa að máta sig við og móta sig eftir „kröfum hópsins“ (Bourdieu, 1977, bls. 14-15) vilji peir verða fullgildir meðlimir hans. Hér verður hugtakið sjálfsmynd notað í pessum víðtæka skilningi, sem sameinar kenningu Bourdieu um ómeðvitaðar tilhneigingar (e. dispositions), meðvitað og persónulegt táknbundið verkefni (sbr. Foucault, Giddens o.fl.) og loks verkfæri til flokkadrátta.

Lykilhugtak í stéttakenningu Bourdieu er auður í víðasta skilningi hugtaksins, en samkvæmt Bourdieu mótast stéttarstaða af mismunandi samsetningu og styrk menningar-, félags- og efnahagsauðs svo og uppsöfnuðum forréttindum peirra kynslóða (e. generational class history) sem á undan hafa gengið (Weininger, 2005). Virkjun auðmagns (e. activation of capital) er mikilvægur liður í að skilja hvernig forréttindi eru endursköpuð (e. reproduced) í gegnum skólakerfið, p.e. 
hvernig fólk nýtir auðmagn sitt í peim tilgangi að hámarka efnislegan og táknrænan hagnað sinn (Lareau og Horvat, 1999). Oft er einnig um að ræða samnýtingu auðmagns og margfeldisáhrifa pegar hátt hlutfall peirra foreldra peirra ungmenna sem sækja tiltekinn skóla telst til auðjöfra 1 efnahagslegu, menningarlegu og félagslegu tilliti (Posey-Maddox, Kimelberg og Cucchiara, 2014; Vincent, Rollock, Ball og Gillborn, 2012). Valferli hvað varðar nám og störf markast pví mjög af félagslegum páttum og sést best á samspili stéttarbakgrunns og kynferðis í slíku ferli (Guðbjörg Vilhjálmsdóttir og Guðmundur B. Arnkelsson, 2013), t.d. í vali á háskólanámi (Porgerður Einarsdóttir og Berglind Rós Magnúsdóttir, 2005) og starfsvali (Katrín Björg Birgisdóttir og Ingólfur Ásgeir Jóhannesson, 2012; Pórður Kristinsson, 2005).

Valferli er hóptengt ekki síður en einstaklingsbundið par sem tengslanet og óformlegar upplýsingar skipta gífurlega miklu máli (Ball og Vincent, 1998; Horvat, Weininger og Lareau, 2003). Orðrómur (e. grapevine) um skóla eða kennara innan tengslanets skiptir miklu og aðgangur að slíkum upplýsingum markast af pví hvar maður býr, hverja maður pekkir og hvaða hópi maður tilheyrir. Allt mótar petta pann félagsauð sem einstaklingar og hópar hafa yfir að ráđa og geta nýtt sér til framdráttar í hinum félagslega veruleika (Bourdieu, 1998). Tengslanet sem lægri stéttir og fátækt fólk hefur aðgang að hafa gjarnan mun færri innanborðs sem „,pekkja kerfið“, „kunna leikinn“ eða vita af smugum til að „,spila á pað“ varðandi val á skóla og samskipti við valdhafa eða sérfræðinga (Berglind Rós Magnúsdóttir og Helga Hafdís Gísladóttir, 2017; Cucchiara og Horvat, 2013; Horvat o.fl., 2003). Val mótast einnig af ómeðvituðum gildum eða smekk (menningarauði) sem hefur greipst inn í undirvitund og mótað veruhátt nemandans, svo sem væntingum, markmiðum, málfari, hreyfingum og framkomu (Bourdieu, 1984). Dess vegna eru ástæður vals oft óljósar pegar fólk er innt eftir peim; val af ákveðnu tagi er einfaldlega pað sem „f́́lk eins og ég“" velur. Dví geta margir hverjir ekki skilgreint fyllilega ástæður vals fyrr en hefðbundnum valmöguleikum „fyrir fólk eins og mig“ er ógnað. Dá verður aðgreining sérlega mikilvæg. Sjálfsmynd einstaklinga og hópa verður til á mörkum „okkar“ og „hinna“ (Hall, 2001). Með pví að aðgreina sig með orðum og gjörðum frá peim sem teljast til lægri stétta í samfélaginu skapar millistéttin sig og endurskapar í sífellu, bæði á efnislegan og táknrænan hátt.

Bourdieu sá fyrir sér að samfélagið væri samsett úr mismunandi vettvöngum (e. fields) sem sköruðust og væru hver öðrum háðir en pó með sjálfstæett regluverk og hagsmuni. Hver vettvangur hefur sínar leikreglur og byggist á valdatengslum milli einstaklinga og stofnana par sem keppt er um ákveðin gæði og auðmagn (Bourdieu og Wacquant, 1992). Síðustu áratugi hafa hægt og sígandi orðið breytingar á leikreglum menntavettvangsins. Ríkjandi áhersla á val í menntakerfinu fékk byr undir báða vængi með albjóðlegum menntastraumum sem byggjast á nýfrjálshyggju og varða m.a. aukna áherslu á árangur, samkeppni, val og einstaklingsábyrgð í stað samfélagsábyrgðar (Berglind Rós Magnúsdóttir, 2013; 2016). Markaðsvæðing í menntun á Norðurlöndum hefur fyrst og fremst einkennst af pví að leikreglum markaðar er komið á innan kerfisins og pá gildir einu hvert rekstrarform skóla er; allir keppa við alla um heppilega neytendur par sem skiptimyntin er gjarnan í formi einkunna (Dovemark o.fl., 2018). Dví geta opinberir skólar hagnast ekki síður en einkareknir af opnuninni fyrir neytendum, svo lengi sem peim tekst að skapa sér sterka stöðu á markaði pannig að peir geti valið úr pá réttu fyrir orðspor skólans.

Markaðsvæðing menntunar hefur ýtt undir pá hugmynd að nám sé eins konar vara (Gewirtz, 2002). •að skýrir að einhverju leyti auknar áherslur í öllum háskólagreinum á skiptigildi peirra á markaði. Sem dæmi um slíkt má taka úttekt á virði skapandi greina fyrir hagvöxt á Íslandi til að réttlæeta nám og störf af pessu tagi og umræða um listir í samhengi við landkynningu og gróða. Раð verður sífellt mikilvægara að auka virði sitt og páttur í pví er að fá inngöngu í „,rétta skólann“. Efnahagslegt auðmagn verður mikilvægt í pessu samhengi, t.d. pegar keypt er aðstoð til að hækka einkunnir og bæta pannig samkeppnisstöðu nemandans. Eins er ljóst að langvarandi lista-, íprótta og/eða tómstundaiðkun á einkamarkaði getur gefið forskot í einhverjum tilfellum, en skólagjöld í listaskólum hafa hækkað umtalsvert á síðustu árum. Pá má minna á að skólagjöld í einkareknum skólum krefjast efnahagslegs bolmagns. 
Með markaðsvæðingu menntakerfisins hefur samkeppni meðal nemenda aukist og par sem hún gengur lengst purfa nemendur allt niður í leikskóla að lúta lögmálum eftirspurnar (Dýrfjörð og Magnúsdóttir, 2016; Vincent, Ball og Braun, 2007). Markaðslögmál í menntun henta sumum betur en öðrum og í pví sambandi er talað um að milli- og efristéttarforeldrar eða fólk sem býr við menningarleg, félagsleg og fjárhagsleg forréttindi hafi forskot, og svo nemendur sem falla vel að viðmiðum skólans um viðurkennda hegðun og námshæfni (Ball, 2006; Gewirtz, 2002). Nemendur með fötlun eða „stimpla“ um krefjandi hegðun, námsörðugleika eða íslensku sem annað mál hafa ekki aðdráttarafl á opnum markaði (Dudley-Marling og Baker, 2012). Pannig gefur auga leið að val er aldrei fullkomlega frjálst, pað hafa ekki allir sömu möguleika á að velja, né búa allir yfir pví auðmagni sem parf til pess að fara tilteknar leiðir í námi eða starfi.

Höfundum pótti pví áhugavert að fá fram raddir nemenda á höfuðborgarsvæðinu, kanna hvernig val peirra markast af veruhætti og samspili hans við vettvang. Pað hvernig nemendur aðgreina sig frá eða samsama sig peirri ímynd sem tilheyrir hinum og pessum framhaldsskólum gefur innsýn í samspil veruháttar og vettvangs. Fjórir framhaldsskólar voru valdir sem rannsóknarvettvangur út frá höfnunarhlutfalli við inntöku nemenda á síðustu fimm árum. Tveir pátttökuskólar hafa hátt höfnunarhlutfall og hinir tveir hafa lágt. Gögnin sem eru notuð í pessari grein eru tölfræðiupplýsingar frá pátttökuskólum um námsferil 97-árgangsins og viðtöl við fjóra til fimm nemendur úr hverjum skóla sem tilheyra 97-árganginum og hófu nám í framhaldsskóla haustið 2013. Viðtölin voru tekin á vorönn 2017, pegar flestir viðmælendur voru að ljúka stúdentsprófi. Viðtölin fólust annars vegar í hálfopnum spurningum og hins vegar í stöðluðum spurningalista til að skilgreina bakgrunn og menningarneyslu. Viðmælendur eiga pað sameiginlegt að tilheyra efsta fjórðungi pess hóps sem tekinn var inn í viðkomandi skóla ef miðað er við inntökuskilyrði hans, og teljast pví vera „góđir“ nemendur í peim skóla. Rannsóknarspurningarnar snúast um pað hvernig pessir „,góðu“ nemendur a) skilgreina skólana og stigveldi peirra, b) hvernig menningarlegir, félagslegir og námslegir pættir móta eða pvinga val peirra á skólum og c) hvernig skólinn mótar hugmyndir nemenda um sjálfa sig og ađra nemendur. Sérstök áhersla er á pá átta nemendur sem gátu talist til rótgróinnar millistéttar (langskólaganga aftur í ættir), p.e. hvað væri eðlilegt fyrir fólk eins og pá.

Dessi grein fjallar um hluta af yfirgripsmeiri athugunum á pví hvort og pá hvernig Íslendingar nota menntakerfið til sjálfsmyndarsköpunar, hópamyndunar og aðgreiningar (í stéttir). Á eftir kaflanum um aðferðafræði taka við fjórir niðurstöðukaflar sem mótast af kenningarlegum hugtökum rannsóknarinnar. Niðurstöður eru svo ræddar og settar enn frekar í samhengi við kenningar og rannsóknir.

\section{Aðferðir og rannsóknarvettvangur}

Rannsóknin er tilviksrannsókn par sem ýmiss konar gögnum er safnað. Megnið af gögnunum er pó eigindlegt. Tekið var hálfstaðlað djúpviðtal við hvern einstakan nemanda sem pátt tók 1 rannsókninni. Meginpættir viðtalsins voru próaðir með hugtakalíkan Bourdieu í huga og eftir aðferðum og niðurstöðum erlendra rannsókna (Berglind Rós Magnúsdóttir, 2014; Reay, Crozier og James, 2011; Reay, David og Ball, 2005). Hugtakalíkan Bourdieu mótar ekki einungis greininguna heldur einnig viðtalsspurningarnar og öll rannsóknartækin. Til að öðlast skilning á veruhætti parf t.d. að spyrja ansi ítarlega um skólasögu og uppruna unga fólksins og daglegar athafnir. Djúpviðtalið byggist á a) skólasögu nemanda, búsetu/aðstæðum, b) lífsstíl, leiðum að skólavali, c) viðbrögðum fjölskyldu og vina gagnvart skólavali, d) reynslu nemanda af skólanum, virkni í félagslífi, sjálfsígrundun og vinatengslum sem og tilfinningalegri reynslu innan skólans, e) framtíðarvæntingum (vali á framhaldsnámi), f) bakgrunni/sýn á eigið uppeldi og g) gildum og pólitískum hugmyndum um menntun. Að djúpviðtali loknu svöruðu nemendur stöðluðum spurningalista (rafrænt) par sem kortlögð var stéttarstaða, tómstundaiðkun og ákveðnir pættir í menningarneyslu unglinganna til að fanga tiltekna sögulega, félagslega og menningarlega pætti. 
Nýttar voru upplýsingar frá menntamálaráđuneytinu til að greina stöđu og stigveldi skóla og geta pannig betur greint samspil og afstöðu veruháttar og vettvangs meðal pátttakenda. Skólarnir sem valdir voru til pátttöku eru á gjörólíkum stað á menntavettvangnum, tveir peirra eru meðal peirra sem hafa lægst höfnunarhlutfall pegar kemur að inntöku nemenda á stúdentsprófsbrautir og tveir peirra eru meðal peirra skóla sem eru með hæst höfnunarhlutfall og taka eingöngu nemendur inn á stúdentsprófsbrautir. Tekin voru 19 viðtöl við framhaldsskólanemendur úr 97-árganginum. Tölfræðiupplýsingum var safnað frá pátttökuskólum um námsferil árgangsins, svo sem um inntökuskilyrði pegar árgangur 97 var tekin inn, hversu margir sóttu um, hve mörgum var hafnað og svo námsgengi árgangsins í gegnum skólann.

\section{Skólarnir fjórir}

Hér er gefið yfirlit yfir ólíka stöðu skólanna er varðar inntöku nemenda og stöðu á menntamarkaði. Skólarnir skiptast í tvö horn hvað varðar höfnunarhlutfall. Darna er stutt yfirlit yfir lágmarkseinkunn/meðaleinkunn 97-árgangsins til að komast inn í skóla með hæst/lægst höfnunarhlutfall, en viðmælendur voru allir fæddir árið 1997.

Tafla 1. Yfirlit yfir ólíka stöðu skólanna varðandi inntöku nemenda og stöðu á menntamarkaði

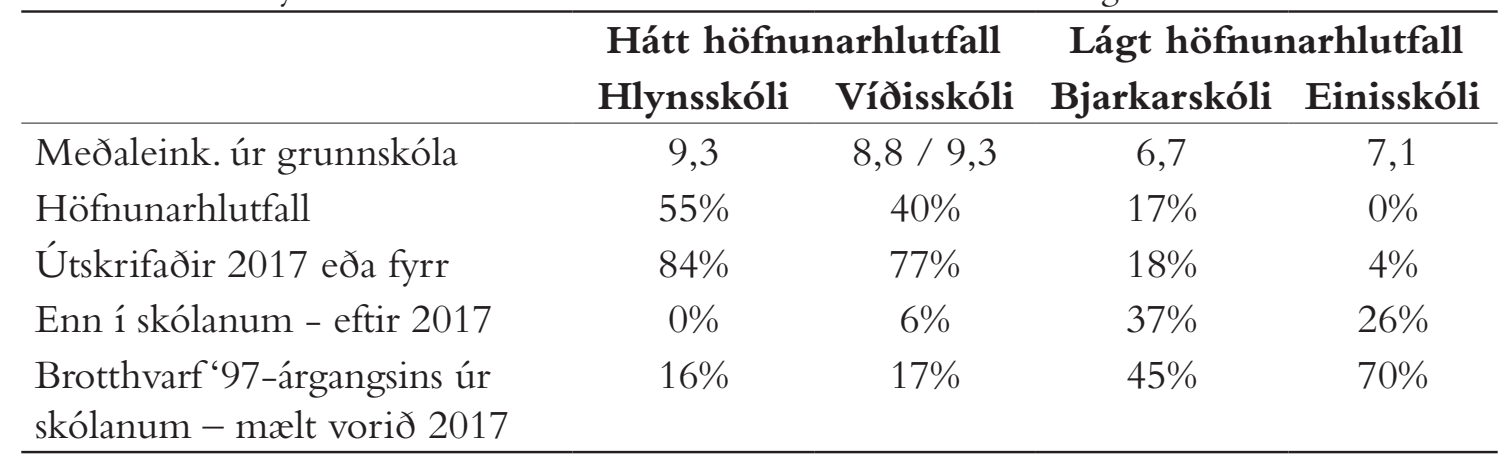

Рað sem er eftirtektarvert við petta er að Hlynsskóli er í einstakri aðstöðu til að velja inn nemendur par sem hann tekur inn minna en helming peirra nemenda sem sækja um skólann í 1. eða 2. vali. Drátt fyrir pað er um 16\% brottfall pessa árgangs úr skólanum. Áfangastjóri tók fram að pessi árgangur kæmi verr út en yngri árgangar skólans.

Í Bjarkarskóla kom í ljós að peir nemendur sem komu inn haustið 2013 og stóđu best að vígi námslega af peim sem sóttu um (efstu 25\%) völdu sér flestir lista- eða ípróttabrautir en ekki hefðbundnar bóknámsbrautir eins og félagsfræði-, mála- eða náttúrufræðibraut. Stór hluti pessa hóps var ekki að fara að útskrifast. Í Einisskóla og Bjarkarskóla gilti yfirleitt að ef nemendur voru á réttu róli og að fara að útskrifast á fjórum árum voru peir meðal peirra $25 \%$ sem voru með hæstu meðaleinkunn við inntöku í skólann. Í Bjarkarskóla dvelja nemendur gjarnan lengur en fjögur ár í skólanum (fyrir utan pá fimm sem luku stúdentsprófi á innan við fjórum árum). Fjöldi útskrifaðra á „réttum tíma“" er lítill í báðum skólunum með lágt höfnunarhlutfall.

\section{Viðmælendur}

Pátttakendur í rannsókninni voru samtals 19 nemendur. Upphaflega stóð til að hafa fimm nemendur frá hverjum skóla, samtals 20, en ekki tókst að fá fimm nemendur í Einisskóla til pátttöku, prátt fyrir ítrekaðar tilraunir. Viðtölin voru flest tekin á vorönn 2017 en nokkur drógust til haustsins 2017, pegar flestir pátttakendur voru pegar útskrifaðir, m.a. vegna pess að nemendur vildu ekki missa tíma frá undirbúningi lokaprófa og útskriftar. Haft var samband við stjórnendur skólanna og peir beðnir að finna nemendur með pað í huga að peir hefðu verið í efsta árangursfjórðungi pess hóps sem tekinn var inn í viðkomandi skóla. Allir viðmælendur töldust pví vera góðir nemendur í sínum skóla. Valið úr pessum efsta fjórðungi átti pó að vera af 
handahófi (kerfisbundið val út frá stafrófsröð peirra í efsta fjórðungi en tryggja jafnframt nokkuð jafnt kynjahlutfall). Рað var misjafnt hvernig skólameistarar unnu petta. Skólameistarar Víðis- og Hlynsskóla sendu fimm nöfn sem áttu að uppfylla pessi skilyrði. Ekki náðist í alla pá nemendur pannig að í einu til premur tilfellum var notuð snjóboltaaðferð og nemendur beðnir að nefna einhverja samnemendur. Í Einisskóla fengum við nöfn á 10 nemendum en pað dugði bó ekki til og við purftum einnig að nota snjóboltaúrtak fyrir tvo nemendur. Í Bjarkarskóla reyndist ekki vera nægur fjöldi á hefðbundnum bóknámsbrautum til að uppfylla pessi skilyrði og pví voru teknir með tveir nemendur sem komu annars vegar af ípróttabraut og hins vegar af listnámsbraut, en báðum brautum er lokið með stúdentsprófi. Аð lokum er vert að nefna að viðmið voru sett um að nemendur pyrftu helst að hafa verið í skólanum frá upphafi. Dað skilyrði purfti hins vegar að rýmka til að ná inn nógu mörgum viðmælendum úr efsta fjórðungi í skólunum með lágt höfnunarhlutfall. Nokkrir viðmælendur höfðu pví komið inn í skólann eftir eina eða tvær annir í öðrum skólum og höfðu pví reynslu af öðrum skólum. Tölfræðigögnum um hvern og einn var safnað með pví að láta nemendur fylla út eyðublað í tölvu strax eftir viðtalið og spyrill var viðstaddur til að útskýra spurningar ef purfti.

Gögnin í rannsókninni eru yfirgripsmikil. Fyrir týpugreininguna (niðurstöðukafla 1) voru öll viðtölin nýtt en til að svara spurningum sem varða samspil veruháttar og vettvangs var sérstaklega rýnt í viðtöl við pá nemendur í hópnum sem uppfylla viðmið um pað sem við kjósum að kalla rótgróinn millistéttaruppruna. Раð reyndist eiga við um átta af viðmælendunum. Nær allir pátttakendur úr Víðisskóla, 4/5, voru með slíkan bakgrunn, 2/5 úr Hlynsskóla og svo einn nemandi úr hvorum skólanum með lágt höfnunarhlutfall. Hjá pessum hópi komu hefðbundin millistéttargildi skýrast fram og pví áhugavert að greina hvernig ungmennin finna sig á ólíkum skólavettvöngum.

Rótgróinn millistéttaruppruni pýðir að pau áttu móður- og/eða föðurforeldra sem bjuggu við menningarleg forréttindi, að pví leyti að pau höfðu aðgang að framhaldsmenntun pegar slíkt var aðeins mögulegt fyrir fáa. Við greiningu kom í ljós að pað sem pessir nemendur eiga sameiginlegt er að peir og fjölskylda peirra falla inn í hina viðteknu hugmynd um millistéttina, ekki ólíka pví sem ameríski draumurinn gaf fyrirheit um (Hochschild og Scovronik, 2003), sem einkennist af stöðugri búsetu og hjónabandi foreldra sem báđir hafa sótt sér háskólamenntun og sinna í flestum tilvikum sérfræði- eða stjórnunarstörfum. Unglingarnir höfðu kerfisbundið stundað ípróttir í æsku og sumir hverjir einnig listnám og höfðu átt fremur átakalitla leik- og grunnskólagöngu. ${ }^{1}$ Deir voru ýmist í engri (Albert, Sigurvin, Breki, Guðbjörg) eða lítilli vinnu með skóla (Helga). Рað er orðið stétttengdara en áđur hverjir hafa möguleika á pví að vinna ekki með skóla og nýta sér pað. Færst hefur í vöxt að unglingar í lægri stéttarlögum purfi að vinna mikið með skóla til að skaffa til heimilisins (Margrét Einarsdóttir, 2014). Nemendurnir af rótgróinni millistétt höfðu aldrei velt fyrir sér verknámi og voru allir með skýr framtíðarplön um háskólanám, jafnvel allt frá barnæsku. Detta er hópur sem nýtur sérstöðu m.t.t. baklands.

\section{Niðurstöður}

\section{„Týpurnar" sem einkenna skólana: Sjálfsmyndarsköpun og félagsleg aðgreining}

Ljóst er á orðum viðmælenda að skólaval er mikilvægur páttur sjálfsmyndarsköpunar og leið til pess að staðsetja sig bæði á efnislegan og táknrænan hátt í hinu félagslega stigveldi. M.ö.o. má segja að val á skóla sé ákveðinn stéttvísir í heimi unglinganna par sem aðgreining og aðgreiningarpörf er skýr. Hér verður reifað hvernig tilteknar „týpur“ einkenna og jafnvel virðast skilgreina skólana, ef miðað er við orð viðmælenda, en merkingarhlaðnar flokkanir nemenda á skólum stýra vali upp að vissu marki. Með pví að velja sér skóla eru nemendur oft á ómeðvitaðan hátt að tengja saman veruhátt sinn og viðeigandi vettvang, skapa sjálfsmynd sína og samsama sig tilteknum

\footnotetext{
Fyrir utan átök í tengslum við „,nördastimpil“ hjá einum drengjanna í grunnskóla.
} 
hópum. Ljóst er að fyrir mörgum er mikið í húfi. Í skólavalinu felst jafnvel ákvörðun um pað hvers konar manneskja peir ætla að verða í samfélaginu.

Deir sem hafa yfir að ráđa ríkulegu efnahagslegu auðmagni og hafa hug á að virkja pað enn frekar virðast fyrst og fremst velja Hlynsskóla ef marka má orð nemenda: „... flestir koma frá mjög efnuðum fjölskyldum ...". Аð sama skapi virðist orðræða viðmælenda um „týpurnar“ nokkuð einsleit og endurspeglar hún fyrrnefnda aðgreiningu. Talað er um nemendur í Hlynsskóla pannig að „ef pú átt ekki alveg svakalega dýran bíl eða átt ekki nýjustu gerð af síma pá passarðu ekki inn“ (Guðbjörg, Víðisskóla), og eins að nemendurnir fái ,allt upp í hendurnar“, séu „,cocky“ (Sigurvin, Einisskóla), „ríkt lið“ og „,dekrað lið“ (Gunnar, Hlynsskóla). Einnig er staðalmyndin af Hlynónemanda fyrst og fremst byggð á efnahagsauði sem á sér táknræna skírskotun í merkjavöru og feðrum sem ríkum fyrirvinnum: „Bara alveg eins og allir eru parna bara, Nike skór, Iphone, pabbi splæsir" (Ólafur, Bjarkarskóla). Aðgengi að vettvangnum og möguleikar til samsömunar við „týpu“ skólans virðast pví ráđast af hlutfallslega miklu efnahagslegu auðmagni.

Veruhátturinn sem tengdur er Víðisskóla virðist að sama skapi vera mjög vel afmarkaður en par hefur annars konar auðmagn hæsta gengið, eða tiltekinn menningarauður, sem getur bæði haft skiptigildi líkt og námsárangur og prófgráđur en einnig menningarauður sem hefur meira táknrænt notagildi til eigin sjálfsmyndarsköpunar og til ákveðinnar menningarneyslu (Devine, Savage, Scott og Crompton, 2005; Savage, Warde og Devine, 2005). Tiltekin viðhorf til náms eru fyrirferðarmikil og birtast skýrt í máli nemenda en lögð er áhersla á að peir sem sækja Víđisskóla séu „nördar“ og „proffar“ og í peim skilgreiningum felst að slíkir nemendur séu „metnaðarfullir“, „duglegir", „klárir“ og „hafa gaman af að standa sig vel í prófum“. Bent hefur verið á (Reay, 2010; Reay o.fl., 2011) að slík orðræða sé mjög einkennandi fyrir rótgróna millistétt, en aðgreiningin er réttlætt sem vísun í eðlislæga eiginleika og pannig er hún jafnframt fest í sessi. Hér má augljóslega sjá verðleikaræðið að verki en sú rökvísi einkennir oftar en ekki orðræðuna um skólaval. Viðkvæðið er almennt pað að persónulegir eiginleikar óháð aðbúnaði og auðmagni ráđi pví hver fái aðgang að vinsælustu skólunum.

Mikil áhersla er á að nemendur sem velja pennan skóla stefni almennt hátt í lífinu og að skólagangan sé leið til pess að „læra að læra“ (Helga, Víðisskóla), að tileinka sér leikreglurnar innan millistéttarinnar með ákveðnu verklagi og vinnusemi sem aðrir skólar krefjist ekki í sama mæli og muni svo skila sér í meiri velgengni í lífinu. Að sama skapi er litið svo á að námið par sé betra en annað nám og jafnvel að kennararnir séu „betur menntaðir“ og „betur gefnir“ (Einar, Víðisskóla) en í öðrum skólum. Annars staðar kom fram að menntun kennaranna, a.m.k. eldri kynslóðarinnar, væri svipuð í framhaldsskólunum sem um er rætt (Ásgerður Bergsdóttir og Berglind Rós Magnúsdóttir, 2018). Síðast en ekki síst er rétt að nefna að nemendahópurinn í Víðisskóla virðist vera pjóðernislega einsleitur ef miðað er við orð viðmælenda:

Рað var enginn af öðrum húðlit í bekknum mínum eða árganginum jafnvel, held ég. Ekkert sem ég tók eftir, pú veist, pað var enginn sem var hérna ... hvað segir maður ... enginn sem var í hjólastól eða neitt pannig (Guðbjörg,Víðisskóla).

Рað var enginn krakki af öðru pjóðerni í mínum bekk í Víðó í gegnum alla mína skólagöngu (Páll,Víðisskóla).

Degar orð viðmælenda í skólum með lágt höfnunarhlutfall (Einisskóla og Bjarkarskóla) eru borin saman við lýsingarnar hér að framan er ljóst að ýmislegt ber á milli. Nemendahópurinn virðist vera mun fjölbreyttari. Aðgreining er gerð á allt öðrum forsendum og önnur gildi virðast ríkja. Orðrómur um pær „týpur“ sem sækja skólana er almennt neikvæður eins og sést á orðum Davíðs (Einisskóla): „Nemendahópurinn er svo mismunandi. Dað er svona kannski aðallega, steríótýpan er pessi, pú veist, tossi, gengur ekki vel í skóla, fór í Einisskóla, komst ekki inn í, pú veist, Asparskóla eða, pú veist, whatever, Hlynó, par sem fólk sækir um.“ Рað virðist jafnvel fylgja pví ákveðin brennimerking að ganga í Einisskóla, eða eins og Sigurvin segir: 
En frá svona samfélaginu, og pegar fólk spurði „í hvaða skóla ertu?“ „Einó“ „jááá“. Pú veist! og maður sá pað alveg á peim að pá hélt pað bara að ég væri, væri að fá fimmur og hefði gengið hryllilega í grunnskóla og bara vissi ekki neitt í minn haus. Mér leið alltaf rosalega illa með pað ... Раð er horft á mann allt öđruvísi og allir halda að maður sé bara heimskur og ... pað er bara klárt mál að pað sé pannig, sko ... (Sigurvin, Einisskóla).

Detta sjónarmið kom skýrast fram meðal nemenda af rótgrónum millistéttaruppruna sem voru vanir virðingu og væntingum um velgengni. „Einótýpan“ er pannig skilgreind sem annars flokks nemandi, með laka námsgetu, lítinn metnað og jafnvel litla greind.

Hins vegar tala flestir peir nemendur sem rætt var við úr Einis- og Bjarkarskóla um skort á innri aðgreiningu (e. inclusive) sem einn af helstu kostum skólans. Рað virðist fylgja pví frelsi til pess að „,vera hver sem er“ (Sigurvin, Einisskóla), ,vera maður sjálfur“ og „,menn bara leyfa fólki að vera eins og pað er“" (Albert, Bjarkarskóla). Jafnframt er litið á fjölbreytileikann sem ákveðið auðmagn (Byrne, 2006), eitthvað sem víkkar út sýn, menningarneyslu og reynslu (e. multicultural capital) (Berglind Rós Magnúsdóttir, 2018; Reay o.fl., 2011).

Dað er kostur líka að petta er svona fjölbreytt umhverfi, fólk frá mismunandi pjóðernum ... (Albert, Bjarkarskóla)

Ljóst er að aðgreiningarpörfin er minni í skóla með lágt höfnunarhlutfall. Skólinn sem vettvangur (e. field) er ekki jafn útilokandi. Orð Hrefnu (Einisskóla) lýsa pessu vel: „Фað eru svo margir hópar parna og pað passa allir inn einhvers staðar. Рað er bara fullkomið, sko." Hins vegar purfa peir gjarnan að vera í vörn út á við. Nemendur eru meðvitaðir um fordómana og passa sig jafnvel á að halda pví leyndu að peir séu parna í námi, pó að peim finnist skólinn sem slíkur góður: „Og maður fær alltaf svona létt svona „Ég ætla ekki að segja að ég sé í Einó kannski við einhverja stelpu eða eitthvað svona dæmi“ (Davíd, Einisskóla). Dau taka pví á sig skömm fyrir að tilheyra skóla og/eða nemendahópi sem telst ekki vera nógu merkilegur í samfélaginu.

Með öðrum orðum eru nemendur mjög meðvitaðir um að ef pau nefna nafn framhaldsskóla síns muni viðmælandinn um leið staðsetja pau og skapa sér ímynd um pau sem nemendur og jafnvel persónur. Skólinn var pví orðinn að eins konar vörumerki. Баð hafði almennt jákvæð áhrif á sjálfsmynd peirra sem voru par sem vörumerkið var hátt skrifað, eins og hjá Guðbjörgu úr Víðisskóla: „En ég hef líka tekið eftir pví að pað er svolítill hroki í Víðó-ingum, bara upp til hópa [hlær].... Og ég hef alveg tekið eftir pví hjá sjálfri mér líka og ég reyni yfirleitt að stoppa pað, ef ég tek eftir pví." Ríkjandi veruháttur (týpa) virðist ekki vera jafn vel skilgreindur eða mótaður í peim skólum sem taka við fjölbreyttum hópi nemenda.

\section{Mikil samsvörun milli veruháttar og vettvangs}

Ljóst er að nemendur úr rótgróinni millistétt sem fóru í Víðis- og Hlynsskóla upplifðu yfirleitt ekki átök í tengslum við skólavalið pví peir vissu að námsárangur peirra tryggði peim pláss í skólanum og fjölskyldu og vinum fannst valið mjög við hæfi. Detta var jafnan hugmynd sem eiginlega purfti ekki að ræða pví vinir og fjölskylda einfaldlega bjuggust við pví:

Ég held að flestir bjuggust bara við pví, skilurðu (R: Mhm, og hvað völdu peir, bestu vinir pínir?) Bestu vinkonur mínar, við skiptumst upp bara í tvo hópa, við fórum, pú veist, ég held að við vorum fjórar sem fórum íVíðó og fjórar í Hlynó, ... pannig að við skiptumst alveg upp (Helga,Víðisskóla).

Í peim tilfellum sem vinahópurinn var talin skiptast upp náði pað yfirleitt ekki miklu lengra en milli Hlyns- og Víðisskóla og sýnir vel hvað val peirra er afmarkað og pröngt. Stórfjölskyldan hafði meira og minna farið í pessa skóla: 
Mamma var íVíðisskóla og hún vildi alveg að ég færi í hann ... Pabbi var svona, pað var mjög áberandi hvað pað var mikið skólastolt af Hlynó, sko. ... ömmu fannst bara flott að ég færi í Vỉisskóla. Hún á náttúrulega helling af barnabörnum og flest fóru í Hlynó og svona en, já, hún var samt bara sátt, sko. (Helga,Víðisskóla)

Helga var nokkuð dæmigerð fyrir rótgrónu millistéttina, p.e. að bæði vinir og foreldrar áttu sinn pátt í pví að í huga Helgu komu aðeins pessir tveir skólar til greina. Breki (Hlynsskóla) hafði lengi stefnt á læknanám og pegar kom að framhaldsskólavali voru einungis pessir tveir skólar sem komu til greina, par sem ,,petta eru einu almennilegu skólarnir“ samkvæmt peim viðhorfum sem ríkjandi eru í fjölskyldu Breka. Degar Breki hafði skoðað Víðisskóla vel og hafnað honum var pað „náttúrulega bara Hlynó“ sem kom til greina. Breki valdi Hlynsskóla að hluta til í peim tilgangi að „endurmóta ímynd“ sína og pannig jafnvel losna við pann „nördastimpil“ sem hann hafði lengi haft og verið honum til trafala í drengjahópnum í grunnskólanum. Auk pess var nokkur prýstingur frá fjölskyldumeðlimum á að velja Hlynsskóla enda mætti í raun skilgreina hann sem fjölskylduskólann. Hann hafði í raun aðeins um tvo kosti að velja, pó öðrum væri vissulega haldið að honum af meiri ákefð, og eins og hann segir sjálfur „,ætti maður sig við pað og fór pangað“.

Hið sama er upp á teningnum hjá Guðbjörgu, en pegar hún er innt eftir ástæðum skólavals á hún erfitt með að útskýra hvaða hvati hafi búið að baki. Dó bendlar hún pað helst við sögu fjölskyldunnar, pá staðreynd að tvö af premur systkinum hennar höfðu á undan henni gengið í Vỉisskóla. Í raun kom aldrei annað til greina en að fara pangað: „Og í rauninni ... ég held að ég hafi ekki farið á neinar kynningar í öđrum skólum.“ Líkt og á við um alla viðmælendur í rannsókninni sem telja má til millistéttar kom ekki til álita að fara í verknám: „Langar pig að fara í verknám? Dú veist, pað var enginn sem spurði mig svona beint að pví ... (Guðbjörg, Víðisskóla).

Raunar fellur veruháttur Guðbjargar vel að peim félagslega vettvangi sem Víðisskóli er enda voru viðbrögð ættingja og vina við skólavalinu á pá leið að „,pað kom engum á óvart ... allir bjuggust við pví, held ég, já, ég var einmitt valin eitthvað svona „bjartasta vonin“ og eitthvað ...“ Hér birtist ljóslifandi sú hugmynd sem ríkjandi er að bein tengsl séu á milli framúrskarandi framavona og vals á tilteknum skóla. Ef pér á að ganga vel pá átt pú að velja pessa skóla. Eins og hjá Helgu skipta félagstengslin máli pegar kemur að skólavali en allar nánustu vinkonur Guðbjargar völdu Víđisskóla og komust inn í skólann. Líkt og í tilfelli Breka er ljóst að valið byggist ekki aðeins á pví sem Guðbjörg „,vildi“ pegar kom að námi, enda segir hún sjálf: „,Mundi ég vera sama manneskjan ef ég hefði ekki farið sömu leiðina í námi? Og pá voru svona helstu skólarnir Greniskóli og Hlynó. Mér fannst einmitt mjög spennandi með Greniskóla að geta tekið nám á styttri tíma og pá áfanga sem maður vildi. Svona nákvæmlega pað sem pú vildir." Af pessum málflutningi mætti draga pá ályktun að önnur öfl hafi verið að verki í skólavalsferlinu en einungis einlægur áhugi á náminu í Víðisskóla. Hér birtast ljóslifandi pær skorður sem vali eru settar, hvernig ætlast er til að meðlimir millistéttar velji skóla sem fellur að veruhætti peirra og gerir svo pað að verkum að aðrir möguleikar falla utan sjóndeildarhrings. Dannig aukast líkur á að forréttindastaðan sé endursköpuð og aðgreiningu og einsleitni innan tiltekinna skóla sé jafnframt viðhaldið.

\section{Degar veruháttur og vettvangur eru á skjön}

Í tveimur tilfellum af pessum átta rótgrónu millistéttungum má segja að pað verði árekstur milli veruháttar og vettvangs. Dað er hjá Sigurvini að öllu leyti pví hann komst ekki inn í Hlynsskóla og endaði í Einisskóla og hjá Albert að pví leyti að hann valdi námsbraut (listnám/ípróttabraut) í Bjarkarskóla sem hefur sérstöðu og aðgreiningargildi almennt en er staðsett í skóla með lágu höfnunarhlutfalli.

... bara vinur minn sagði í djóki, sko, af hverju ég kæmi ekki í Grenó, sko, pað væru líka listáfangar par, sko ... en ég veit pað ekki, ég bara hafði miklu meiri áhuga á að fara hingað, en petta var aldrei neitt svona: Hvað er að pér? eða neitt svoleiðis (Albert, Bjarkarskóla). 
Albert fær hvatningu frá vinum til að fara ekki í Bjarkarskóla pví mögulega væri hægt að finna listtengda áfanga í skóla með háu höfnunarhlutfalli. Hins vegar eru foreldrar hans listmenntaðir og vinna á peim vettvangi og hann var með skýra framtíðarsýn um sjálfan sig sem listamann og vildi einfaldlega fara pangað sem stærsti hluti námsins uppfyllti pau markmið. Sigurvin er sá eini í pessum hópi sem telja má að hafi verið pvingaður í allt aðra átt en hann vildi og fór, ólíkt öllu sínu fólki, í Einisskóla en ekki í Hlynsskóla.

Dau (foreldrar mínir) voru náttúrulega bæði í Hlynó, og amma og afi og allir. Dannig að maður var bara „Jæja, ég parf að fara î Hlynó.“ " Рað var pressa, sko... (R: En bræður pínir, fóru peir í Hlynó?) Já (hlær). Pannig að pað hafa allir farið í Hlynó nema ég (Sigurvin, Einisskóla).

Degar veruháttur er rótgróinn í millistétt kynslóð fram af kynslóð reynist enn erfiðara að fara inn á vettvang sem telst í raun ekki með sem möguleiki og skilgreinist langt fyrir neðan pann vettvang sem ,allir“ í ættinni hafa menntast á. Degar veruháttur og vettvangur eru ólíkir pá hefur skólavalið pvingandi áhrif á sjálfsmyndina og breytir henni jafnvel og pau neyðast jafnvel til að opna á eitthvað sem pau hefðu annars ekki gert. Pau standa ein og purfa að kynnast nýjum leikreglum og fólki. Dessi reynsla pvingaði Sigurvin til að víkka tengslanet sitt yfir til fólks sem hann hefði annars ekki gefið tækifæri: ,,pað hefur breytt mér alveg að kynnast fólki, miklu léttara finnst mér...". Kynnin voru hins vegar ekki endilega djúp vinatengsl og honum fannst hann ekki finna „péttan hóp“ sem hann taldi „sínar týpur“:

Ég á reyndar alveg fullt af vinum sem eru í Einó sem ég alveg heng með alveg af og til. En pú veist ég heng aðallega með mínum grunnskólanemend..., félögum. Hinir eru meira svona kunningjar og góđir félagar sem ég hitti af og til. ... í Einisskóla fannst mér ég ekkert finna einhvern péttan hóp sem mér fannst ég eitthvað tilheyra pannig séð, bara ekki mínar týpur ... (Sigurvin, Einisskóla)

Hans vinahópur er eftir sem áđur gömlu vinirnir úr grunnskóla og hann sækir nú eingöngu viðburði í Hlynó eða öðrum skólum par sem honum finnst hann frekar tilheyra.

R: En fólkið sem pú ert svona mest með núna, er pað með svipaðan bakgrunn og pú sjálfur?

S: Já, alveg 100\%, sko.

R: Mhm, hvernig pá? Hvernig bakgrunnur er pað?

S: Einfaldan, léttan. Eitthvað svona frá (X-hverfi með mjög hátt efnahagskapítal), áttum ekkert erfitt ... fjárhagslega, eitthvað pannig. Pannig að við vorum allir mjög hamingjusamir og allt, enginn átti í einhverjum erfiðleikum með foreldra sína og ... Pannig, ég held að pað sé svona ... já. Bara, ólumst allir svipað upp, erum alltaf saman. ... Förum alltaf saman til útlanda á hverju ári.

Svipaða sögu er að segja af Albert á myndlistarbrautinni í Bjarkarskóla. Hann telur sig hafa lært mikið af pví að „kynnast“ fjölbreyttum hópi fólks en tengist fyrst og fremst hópnum á listabrautinni.

раð er kostur líka að petta er svona fjölbreytt umhverfi, fólk frá mismunandi pjóðernum ... ég veit pað ekki, pað er náttúrulega kostur, pað er ekki bara pað, en pað er bara svona mjög fjölbreyttur hópur, sko, og ... hmmm ... já síðan annars hef ég bara verið mikið á listabrautinni og í kringum fólkið á listabrautinni, sko (Albert, Bjarkarskóla).

Ljóst er að einhæft brautaval í skólunum með hátt höfnunarhlutfall pvingaði tiltekna nemendur eins og Albert til að yfirgefa nærsamfélag sitt til að sækja sér pá menntun sem peir raunverulega vildu og halda sig staðfastlega við að velja skóla meira á forsendum inntaksins í náminu en að láta 
orðspor skólans eða vörumerkið ráða för. Í einum pessara fjögurra skóla með hátt höfnunarhlutfall á höfuðborgarsvæðinu er ekki einu sinni hægt að velja braut félagsvísinda, hvað pá listnámsbrautir, og pað pvingar pá nemendur sem velja stöðu umfram inntak náms til að laga sig að enn einhæfara námsvali en ella.

\section{Að átta sig á eigin forréttindum}

Dóttflestirviðmælendanna viðurkenni að bakgrunnurgeti vissulega haftáhrifáframhaldsskólavalið er ljóst að einstaklingshyggjan og verðleikaræðið er undirliggjandi rök í viðhorfum peirra. Flestir viðmælendur nefna ólík viðhorf, löngun, getu og hugsunarhátt sem ráðandi pætti pegar kemur að námsgetu og vali á framhaldsskóla. Páll úr Víðó lýsir bví hvernig bakgrunnur getur haft áhrif á námsárangur: „Đá er maður kannski með mismunandi viðhorf fyrir menntuninni og einhverju starfi og er að haga sér mismunandi." Í sama streng tekur Helga úr Víðó sem segir að ef maður á erfitt heima fyrir sé maður „kannski ekki alinn upp við bann hugsunarhátt að vera duglegur“. Páll leggur áherslu á að valið byggist fyrst og fremst á persónubundinni námsgetu: „... krakkarnir eru náttúrulega líka að velja menntaskóla eftir sinni eigin getu, bað fer ekkert hver sem er inn í Hlynó eða inn í Víðó“. En námsgetan byggist ekki bara á meðfæddum námshæfileikum heldur fyrst og fremst metnaði og dugnaði ef tekið er mið af orðum viðmælenda. Alltumlykjandi er orðræðan um ábyrgð einstaklingsins og að hann byrji snemma að móta sér athafnaáætlanir (e. strategies) um pað hvernig hann ætli að ná árangri, sem tengist mjög hefðbundnum millistéttargildum (Ball, 2003), eins og sést skýrt á orðum Guðbjargar úr Víðó:

Mér finnst í rauninni að kannski í 8. bekk pá æetti svolítið að fara að hamra inn í hausinn á fólki, bara: „Ef pig langar í annan skóla bara, pá verðurðu bara að taka pig á.“ .... Ég valdi sjálf í hvaða skóla ég fór, pú veist. Ég hefði getað valið Bjarkarskóla, ég hefði getað valið Greniskóla, ég hefði getað valið Lerkiskóla. En, pú veist, ég valdi að fara íVíðó, ... svo einmitt fer pad bara eftir einkunnum, pú veist, hver kemst inn og hver kemst ekki inn. Og pað er bara eitthvað sem að fólk verður að axla ábyrgð á.

Samkeppni er einnig nokkuð ríkjandi pema og pykir ákjósanleg leið til pess að efla bæði gæði kennslunnar og námsgetu nemenda. Hins vegar er ljóst að par skilur á milli peirra rótgrónu millistéttunga sem hafa alið manninn í skólunum með lágt höfnunarhlutfall og svo hinna. Sigurvin og Albert töldu að veran í Einis- og Bjarkarskóla hefði breytt hugsunarhætti peirra og gefið peim víðari sjóndeildarhring. Sigurvin áttaði sig betur á eigin forréttindum og eigin uppruna.

... pegar ég fór úr gagnfræðaskóla pá var maður svona cocky ... bastard eins og maður segir, skilurðu (hlæja bæði) og að fara í Einó breytti mér alveg hvernig ég horfi á fólk.... pannig að maður svona veit hvernig aðrir líða. Pannig, pú veist, ég myndi aldrei dæma manneskju fyrir neitt sem hún vildi vera ... (Sigurvin, Einisskóla).

Dessi reynsla varð til pess að hann endurskoðaði hugmyndir sínar um kerfið sjálft, svo sem pá reglu að sumir skólar gætu eingöngu valið sér nemendur á meðan aðrir tækju við öllum.

Allavega, ekki að hafa eitthvað svona, pú parft að hafa 9,9 til að komast í Hlynó,... Svo, hafa smá fjölbreytileika í menntaskóla, mér finnst pað vera crucial. Bara upp á sýnina peirra á fólkið, upp á framtíðina að gera (Sigurvin, Einisskóla).

Ljóst er að Albert í Bjarkarskóla áttar sig á að umræðan um gæði skólanna markast af peim nemendum sem sækja pá en ekki endilega faglegum áherslum og kennslu: „,.. svolítið svona óréttlátt með pessa stóru skóla Hlynó og Víðó að peir segjast vera bestu skólarnir en peir fá líka bara nemendurna með bestu einkunnirnar ..." Áhugavert er að bera pað misgengi sem birtist hér að framan saman við samspil veruháttar og vettvangs hjá peim nemendum sem flokka mætti til millistéttar og ganga í skóla með hátt höfnunarhlutfall. Pótt sum hefðu gjarnan viljað læra annað 
en boðið er upp á í skólanum virðast pau vera eins og „fiskur í vatni“ í pessu nýja umhverfi og finnst pau alfarið hafa sjálf unnið fyrir pví að vera verðugir fulltrúar skólans. Deim finnst pau geta verið pau sjálf að öllu jöfnu og finna fyrir öryggi innan veggja skólans. Jafnframt virðast pau leggja sig fram um að endurspegla og halda á lofti peim gildum sem par eru ríkjandi, eins og dugnaði, árangri og metnaði. Aðrir nemendur innan skólans hafa að peirra mati svipaðan veruhátt og pau sjálf, eru t.d. „allir hvítir og venjulegt bara“. Veruhátturinn er svo endurskapaður í gegnum samskipti við nemendur með svipaðan bakgrunn, sömu gildi og sambærileg áhugamál. Degar pau eru spurð hvort pau hafi breyst á einhvern hátt við veruna í skólanum er algengast að talað sé um aukna námsgetu, aukið sjálfstraust eða nýjan áhuga á námi eða stjórnmálum.

\section{Samantekt og umræða}

Samkvæmt niðurstöðum rannsóknarinnar er auðmagni á vettvangi framhaldsskólans mjög misdreift milli skóla. Í skólum með hátt höfnunarhlutfall eru hópar nemenda sem hafa náð mjög góðum námsárangri og ljúka stúdentsprófi á réttum tíma (84\% og 77\%) á meðan skólar með lágt höfnunarhlutfall taka við nær öllum nemendum óhád námsárangri og hafa lágt hlutfall útskrifaðra á réttum tíma (18\% og 4\%). Um eða yfir helmingur 1997-árgangsins í peim skólum er fallinn brott úr náminu pegar komið er upp á fjórða námsár (2017) í samanburði við 16-17\% í skólunum með hátt höfnunarhlutfall. Dað mega teljast merkar niðurstöður í sjálfu sér hversu erfitt reyndist að ná fullnægjandi fjölda nemenda í viðtal í Einisskóla, pó að peir teldust vera í efsta árangursfjórðungi árgangsins í skólanum. Í umræu um árangur í skólastarfi er yfirleitt ekki talað um áskipuð eða uppsöfnuð forréttindi hópa eða stofnana. Bourdieu var einn af peim fyrstu sem afbyggði hugmyndina um að verðleikaræði með gögnum um franskt menntakerfi og benti á samspil sögulegra og félagslegra pátta sem mótuðu umræðu og hugmyndir um gæði skóla og námsframvindu einstaklinga (Bourdieu, 1973, 1998; Bourdieu og Passeron, 1977).

Рað er mikið í húfi pegar kemur að framhaldsskólavali, bæði hvað varðar sjálfsmynd einstaklingsins og pá framtíð sem hann telur að bíði sín. Leiða má líkur að pví að val á framhaldsskóla sé mikilvægur liður í endursköpun eigin stéttarstöðu hjá rótgróinni millistétt. Meðal pessa hóps er gengið út frá pví að velgengni í lífinu velti að miklu leyti á framhaldsskólavalinu og nemendur velja skóla út frá peim veruhætti sem talinn er einkenna skólann sem félagslegan vettvang, p.e.a.s. út frá peim „týpum“ sem peir samsama sig við. Hér eru á ferðinni óræðar væntingar um pað hvers konar manneskja hver og einn ætlar að verða í samfélaginu og af orðum viðmælenda er ljóst að hugmyndir um „týpurnar“ eru prástef og hafa sannleiksgildi í huga peirra. „Týpan“ í Hlynsskóla býr yfir miklu efnahagslegu auðmagni sem birtist á táknrænan hátt í notkun merkjavöru og feðrum sem ríkum fyrirvinnum. „Týpan“ í Víðisskóla býr yfir menningarlegri fágun, mikilli greind og stefnir hátt í lífinu. „Týpurnar“ í skólum eins og Einisskóla og Bjarkarskóla eru óræðari og hafa neikvæða skírskotun nema pegar nemendur geta varið sig með pví að vera á tilteknum brautum (listabrautum). Týpan sem talin er einkenna skólann virðist, samkvæmt orðum viðmælenda, hafa að jafnaði lítinn metnað, laka námsgetu og jafnvel litla greind. Davíð og Sigurvini úr Einisskóla, sem stunduðu nám á hefðbundnum námsbrautum bóknámsins, fannst peir fá neikvæð viðbrögð og fólk jafnvel missa álit á peim pegar upp komst að peir tilheyrðu nemendahópnum par.

Prýstingurinn er pó sérstaklega mikill hjá peim sem flokka má til rótgróinnar millistéttar par sem skólavalið er leið til pess að staðsetja sig í hinu félagslega stigveldi og festa í sessi pau forréttindi sem pau búa nú pegar yfir. Oft er bæði prýstingur frá fjölskyldu og vinum á að velja „rétta“ skólann par sem „rétt" tegund af nemendum á heima og endurspeglar gæði hans. Niðurstöður rannsóknarinnar sýna að val peirra er í raun takmarkað val. Í fræðilegri umræðu er oft talað um pá staðreynd að lægri stéttir hafi ekki raunverulegt val pegar kemur að pví að velja framhaldsskóla en af pessum niðurstöðum að dæma á að einhverju leyti hið sama við um rótgróna millistétt, fyrir utan pá fáu nemendur sem velja að fara út fyrir sinn upprunavettvang vegna tiltekinna námsbrauta. Ástæður pvingunar eru einfaldlega af öðrum toga. Krafa er um að virkja auðmagn sitt í gegnum skólavalið og hámarka hagnað sinn í hinum félagslega veruleika 
(Lareau og Horvat, 1999). Hér parf pó að benda á Albert sem valdi listabraut í Bjarkarskóla. Hann sá ekkert annað fyrir sér par sem báðir foreldrar hans tengdust listum, hann hafði sótt nám í sérskólum meðfram grunnskólanámi sínu alla sína barnæsku og petta var eina listnámið að hans mati sem framhaldsskólakerfið bauð upp á í hans listgrein. Dar trompaði námsval sjálft skólavalið og stjórnaðist af rótgrónum fjölskylduböndum við listagyðjuna fremur en við tiltekna skólastofnun.

Tilgangur Bourdieu-ískrar greiningar af pessu tagi er ekki að gera lítið úr neinum heldur að reyna að skilja hvað pað er sem drífur áfram tilteknar athafnir og val með pví að rýna í tengslin milli veruháttar og vettvangs.

Ég persónulega pjáist pegar ég sé einhvern fastan í gildru nauðsynja hvort sem pað eru nauðsynjar peirra fátæku eða peirra ríku. (Bourdieu og Wacquant, 1992, bls. 199)

Hér er vitnað í samtal peirra Wacquant og Bourdieu par sem Bourdieu bendir á að peir sem við fyrstu sýn líta út fyrir að hafa frjálst val, svo sem eins og auðjöfrar í menningarlegu og/ eða efnahagslegu tilliti, hafi pað í raun ekki heldur. Deirra eigin veruháttur og svo stéttisminn (e. classism) í samfélagsformgerðinni, sem m.a. má rekja til aukinnar einstaklingsábyrgðar og samkeppni, gerir раð аð verkum að peir upplifa pað sem enn meiri „nauðsyn“ að ganga í pessa skóla sem tróna efst í stigveldinu. Ef tryggð væri meiri breidd í námsárangri í hverjum skóla og pað væru stærri hópar í hverjum peirra sem nemendur gætu samsamað sig við er líklegra að skólavalið yrði opnara og afslappaðra og pað færi meira að snúast um námsval. Eftir að farið var að nota menntakerfið í meiri mæli til aðgreiningar og sjálfsmyndarsköpunar hefur kvíði millistéttarinnar aukist (Yoon, 2016). Brattara stigveldi milli skóla felur í sér harða dóma um pað hversu verðugar eða óverðugar „týpur“ sækja tiltekna skóla. Æ meir hefur purft að treysta á menntakerfið og langt nám á háskólastigi til að geta endurskapað stéttarstöðu sína (Reay, 2005). Eftir pví sem fólki með háskólagráður hefur fjölgað hafa einnig skilin á milli peirra sem menntast í „réttum skólum“ og svo hinna orðið skýrari (Power, Edwards, Whitty og Wigfall, 2003).

Degar rýnt er í ástæður vals samræmast niðurstöður vel kenningum Bourdieu; „Val eða athafnir eru ekki kaldranalegir útreikningar á mögulegum hagnaði heldur ómeðvituð tengsl milli veruháttar og vettvangs“ (Bourdieu, 1993, bls. 76). Samspil veruháttar, auðmagns og vettvangs kemur hér til skjalanna par sem saga, reynsla og uppsafnaður auður stýrir áformum, væntingum og sjálfsmynd. Ljóst er að pað er ekki aðeins vilji nemenda eða einlægur áhugi sem stýrir valinu heldur er oft prýstingur frá fjölskyldumeðlimum eða óljósar og ómeðvitaðar væntingar sem eiga pátt í pessu ferli, tilfinningin fyrir pví hvað öðrum af sama sauðahúsi pykir ásættanlegt eða viðeigandi (Bottero, 2010). Баð meðvitaða í ferlinu er löngun til að móta jákvæða sjálfsmynd og leiðin að pví er m.a. að fá pláss í skóla sem nýtur virðingar.

Dað er ekki fyrr en nemendur af rótgróinni millistétt fara út fyrir upprunavettvang sinn sem peir upplifa misgengi milli veruháttar og vettvangs par sem peir ýmist „,passa ekki inn“ eða gera sér far um að samsama sig við hópa í öđrum skólum sem eru nær peim í stéttarstöðu; ,eru peirra týpur“. Gildin frá fjölskyldu og samferðafólki hafa greipst inn í undirvitund (veruháttinn) og ástæður vals eru oft óljósar pangað til hefðbundnum valmöguleikum er ógnað, eins og hjá Sigurvini. Deir tveir nemendur af rótgrónum millistéttaruppruna sem sóttu Einis- og Bjarkarskóla mynduðu ekki sterk vinatengsl í skólunum, eins og oft gerist á framhaldsskólastigi. Pannig endurskapa peir sjálfsmynd sína í andstöðu við aðra nemendur, sem hafa neikvæða skírskotun í almennri umræðu (Hall, 2001). Stéttamunur og aðgreining er pannig oft óljós pangað til nemandi parf að dvelja fyrir utan sinn upprunavettvang og greina má áframhaldandi pörf fyrir samsömun við millistétt og minni áhuga á djúpum kynnum við aðra hópa. Hins vegar hafa kunningjatengslin og veran í skólanum skilað Albert og Sigurvini auknum skilningi á ólíkum aðstæðum fólks og gert pá gagnrýna á pað einfalda gildismat sem einkennir oft umræðu um gæði skóla. Slíkir dómar ýta svo enn frekar undir brattara stigveldi milli framhaldsskólanna. Hin nýja sýn Sigurvins er ágætt dæmi um pað hvernig gildismat einstaklings getur próast og breyst við pað eitt að stíga inn á nýjan og 
ókunnugan vettvang (e. field) og eiga í samskiptum við fólk með ólíkan veruhátt (Bourdieu, 1977). Skoðanir mótast á nýjum vettvangi og millistéttin áttar sig frekar á eigin forréttindastöðu við slíkar aðstæður (Berglind Rós Magnúsdóttir, 2014, 2018; Reay o.fl., 2011).

Aðgreining og einsleitni í tilteknum skólum öðlast lögmæti fyrir tilstuðlan orðræðunnar um verðleikaræði. Áhersla er lögð á að aðgreining í skólakerfinu byggist fyrst og fremst á persónubundnum eiginleikum líkt og dugnaði, greind og metnaði. Pannig aðgreina nemendur í elítuskólum sig frá peim sem ganga í aðra skóla, sérstaklega peim sem hafa lágt höfnunarhlutfall, og á sama tíma frá lægri stéttum sem jafnan er talið að skorti pessa sömu eiginleika. Meðvitund um forréttindi, félagslegan ójöfnuð og stéttarstöðu er takmörkuð og eru pær niðurstöður í samræmi við sambærilegar rannsóknir á erlendri grundu (Reay o.fl., 2011). Sigurvin upplifði sterkt pann tilfinningalega sársauka sem fylgdi pví að vera skilgreindur óverðugur pegar pað barst í tal við kunningjafólk að hann væri nemandi í skóla með lágt höfnunarhlutfall. Davíð sagðist halda pví leyndu við stelpur sem hann væri að hitta að hann væri nemandi í Einisskóla. Nemendur í Einisskóla purftu pví að kljást við alls kyns fordóma, m.a. að peir væru lélegir námsmenn með lítinn metnað. Að nefna nafn framhaldsskóla var eins og að kalla fram tiltekið vörumerki sem annaðhvort gat gefið viðkomandi jákvæða eða neikvæða ímynd. Vörumerkjavæðing framhaldsskólakerfisins nýtist pví með markvissum hætti til sjálfsmyndarsköpunar og viðhalds stéttakerfisins.

Рað er við hæfi að enda á orðum Bourdieu (1993) um mátt félagsfræðinnar til að frelsa okkur frá blekkingunni um frelsið: ,sociology frees us from the illusion of freedom“. Við vonumst til að hafa hér gefið innsýn í flókin mynstur aðgreiningar og sjálfsmyndarsköpunar og hvernig pað ferli er langt frá pví að vera frjálst og óhád. Milli- og efristéttin verður síður fyrir pví sem Bourdieu kallar táknrænt ofbeldi (e. symbolic violence) og leiðirnar sem henni er ætlað að fara gefa gjarnan meiri möguleika á virðingu, valdi og öryggi í samfélaginu.

\section{"Not my type of people!" Students' narratives of choosing the 'right' school for academic tracks in Iceland}

This study focuses on academic-track students and examines how choice between upper-secondary school tracks leading to matriculation exams is perceived by those who live in the largest market area; the Reykjavik capital region. The study is based on Bourdieu's theories, which describe choice as being marked by the relationship between habitus and field and how ideas on school quality are colored by the concentration of privilege of those who belong to the school community. The aim of the study is to imagine whether and, if so, how this applies here in Iceland with regard to students' choice of upper secondary school and matriculation track.

The article is part of a larger study by the first author, which has been supported by the University of Iceland Research Fund (2017). The project is a qualitative case study. The participants consist of 19 students in four different schools: two elite upper secondary schools and two other schools that have low market value among students aspiring for matriculation exams. Both elite schools only have academic tracks for matriculation exams. The lower-ranking schools offer both academic tracks for matriculation exams and art and vocational tracks of many kinds. There is a much wider age distribution of students than in the elite schools, both due to the vocational tracks and also due to access of young people up to 24 years old to enroll in academic tracks integrated with 16 to 20 -year-old students at the upper secondary schools. The interviewees were all born in 1997 and were entering their fourth and last year of study. Each student interviewee participated in a semi-structured interview, theoretically driven by Bourdieu's conceptual framework in mind (Berglind Rós Magnúsdóttir, 2014; Reay et al., 2011; Reay et al., 2005). The students also answered a standardized electronic questionnaire that mapped generational class history, extracurricular activities and certain aspects of their cultural consumption. 
In this article we pay particular attention to those students in the group who fulfill the criteria for being students with generational middle-class history, as having deep middle-class roots. These turned out to be eight of the 19 students, six out of 10 students from the elite schools and one from each of the schools with low market value. Deep middle-class roots mean that they are at least third-generation middleclass, where one or both sets of grandparents possessed cultural privilege, which includes having access to higher education when this was available only to a few. The research questions probe how these "good" students define the schools and their hierarchy and whether and, if so, how students differentiate themselves from others and define their own identity and changes to it through their school choice.

It is clear from participants' words that school choice is an important means for shaping identity and leads them to position themselves both materially and symbolically. In other words, it might be said that school choice is a certain class indicator in the teenagers' world, where differentiation and the need for it are clear. The article discusses how certain "types" seem to define the schools, according to the interviewees. By choosing a school, students are often subconsciously connecting their habitus and an appropriate field, shaping their identity and identifying with certain groups. There is clearly a great deal at stake for many of them. Choosing a school can even entail a decision about what kind of person they are going to be in society.

It is clear that it is not only a student's desire or genuine interest that directs the choice. Pressure from parents and relatives or unclear, subconscious expectations often surround this process, the sense of what others of similar origins find acceptable or appropriate (Bottero, 2010). Students with generational middle-class history do not experience a disjuncture between habitus and field until they go outside their field of origin and either "don't fit in" or make an effort to identify with groups at other schools that are closer in class position to them. The values of family and fellowtravelers have been ingrained into the subconscious (habitus) and the reasons for their choices are often unclear until traditional options are threatened. Distinction based on social class is often uncertain until students dwell outside their field of origin; a continued need to identify with their "own types of people" and lesser interest in close acquaintance with other groups.

Awareness of privilege, social inequality and class position is limited, similar to results shown by research in other countries (Reay et al., 2011). Mentioning the name of an upper-secondary school was like referring to a particular brand that could either be perceived positively or negatively. The "brandization" of the upper secondary school system is systematically used for identity formation and to maintain the class system.

Keywords: Upper-secondary education, school choice, students, identity formation, inclusive education, social class, Bourdieu

\section{Um höfundana}

Berglind Rós Magnúsdóttir (brm@hi.is) er dósent í menntunarfræðum á menntavísindasviði Háskóla Íslands. Hún lauk doktorsprófi 2014 frá Cambridge-háskóla í Bretlandi, MA-prófi í uppeldis- og menntunarfræðum frá HÍ árið 2003 og kennaraprófi frá Kennaraháskóla Íslands 1998. Hún hefur m.a. starfað sem grunnskólakennari, jafnréttisfulltrúi HÍ og ráđgjafi ráðherra í menntamálum. Hún stýrir nokkrum rannsóknarverkefnum sem byggjast á gagnrýnum kenningum og fjalla um félagslegt réttlæti í skólastarfi. Sérstök áhersla er á að varpa ljósi á félagslega aðgreiningu í menntakerfinu og hvernig stétt, kyngervi, uppruni, búseta og sértækar menntunarparfir spila par saman. 
Unnur Edda Garðarsdóttir (ueg1@hi.is) er aðjúnkt og aðstoðarrannsakandi á menntavísindasviði og félagsvísindasviði Háskóla Íslands. Hún lauk MA-prófi í mannfræði árið 2016 og diplómanámi í menntun framhaldsskólakennara árið 2017. Hún hefur starfað sem framhaldsskólakennari og grunnskólakennari auk kennslu við Háskólann. Rannsóknaráhugi hennar snýr að róttækum stjórnmálum og gagnrýnum menntunarfræðum.

\section{About the authors}

Berglind Rós Magnúsdóttir (brm@hi.is) is Associate Professor at the University of Iceland, School of Education. She received her doctorate from the University of Cambridge, UK, in 2014, focusing on American education policy and parental choices and practices in neoliberal times. Her earlier degrees are in teacher education (B.Ed.) and gender and education (MA). She is a principal investigator in several research projects based on critical education theories with a focus on social justice in education. Her area of special emphasis is on understanding the processes of social segregation and distinction within the Icelandic education field and how intersections of social class, gender/sexuality, origin/ethnicity, geographical location and special needs shape possibilities of inclusion.

Unnur Edda Garðarsdóttir (ueg1@hi.is) is an adjunct lecturer and assistant researcher at the School of Education and School of Social Sciences, University of Iceland. She completed her MA in anthropology in 2016 and a diploma in upper secondary school teaching in 2017. Her research interests are in radical politics and critical educational research.

\section{Heimildir}

Ásgerður Bergsdóttir og Berglind Rós Magnúsdóttir. (2018). Ólíkur félagslegur og menntapólitískur veruleiki íslenskra framhaldsskóla: Nám til stúdentsprófs í 20 ár af sjónarhóli framhaldsskólakennara og -stjórnenda. Netla - veftímarit um uppeldi og menntun. Sérrit 2018 - Framhaldsskólinn í brennidepli. Sótt af http://netla. hi.is/serrit/2018/framhaldskolinn_brennidepli/12.pdf

Ball, S. J. (2006). Education policy and social class. London: Routledge.

Ball, S. J. (2003). Class strategies and the educational market:The middle classes and social advantage. London: Routledge.

Ball, S. J. og Vincent, C. (1998). 'I heard it on the grapevine': 'Hot' knowledge and school choice. British Journal of Sociology of Education, 19(3), 377-400.

Berglind Rós Magnúsdóttir. (2013). „Að tryggja framboð og fjölbreytileika“: Nýfrjálshyggja í nýlegum stefnuskjölum um námsgagnagerð. Uppeldi og menntun, 22(2), 55-76.

Berglind Rós Magnúsdóttir. (2014). The cultural politics of middle-classes and schooling: Parental choices and practices to secure school (e)quality in advanced neoliberal times (óutgefin doktorsritgerð). University of Cambridge, Cambridge.

Berglind Rós Magnúsdóttir. (2016). Skóli án aðgreiningar: Átakapólar, ráđandi straumar og stefnur innan rannsóknarsviðsins. Í Dóra S. Bjarnason, Ólafur Páll Jónsson og Hermína Gunnpórsdóttir (ritstjórar), Skóli margbreytileikans í kjölfar Salamanca (bls. 67-94). Reykjavík: Háskólaútgáfan.

Berglind Rós Magnúsdóttir. (2018). Differentiation in middle-class identities, values and responses: Parental choice in a working-class, multi-ethnic school. Í F. J. Levine, L. D. Hill, E. L. Baker, Y. C. Cheng, L. Ebersöhn, O. K. Lee og S. Lindblom-Ylanne (ritstjórar), World Education Research Yearbook (bls. 77-100). New York: Routledge.

Berglind Rós Magnúsdóttir og Helga Hafdís Gísladóttir. (2017). „Đá er gott að fá einhvern utanaðkomandi... sem borin er virðing fyrir“" Bjargráð mæðra við skólagöngu einhverfra barna sinna í ljósi stéttakenningar Bourdieu. Netla - Veftímarit um uppeldi og menntun. Sótt af http://netla.hi.is/greinar/2017/ryn/08.pdf

Bottero, W. (2010). Intersubjectivity and Bourdieusian approaches to identity. Cultural Sociology, 4(1), 3-22. DOI: $10.1177 / 1749975509356750$

Bourdieu, P. (1973). Cultural reproduction and social reproduction. Í R. Brown (ritstjóri), Knowledge, education, and cultural change (bls. 56-69). London:Tavistock. 
Bourdieu, P. (1977). Outline of a theory of practice. Cambridge: Cambridge University Press.

Bourdieu, P. (1984). Distinction: A social critique of the judgement of taste. Cambridge: Harvard University Press.

Bourdieu, P. (1993). Sociology in question (R. Nice býddi). London: Sage.

Bourdieu, P. (1998). The State nobility: Elite schools in the field of power (L. C. Clough pýddi). Cambridge: Polity Press.

Bourdieu, P. og Passeron, J.-C. (1977). Reproduction in education, society and culture. London: Sage.

Bourdieu, P. og Wacquant, L. (1992). An invitation to reflexive sociology. Chicago: University of Chicago Press.

Byrne, B. (2006). White lives: The interplay of 'race', class and gender in everyday life. London: Routledge.

Conde, I. (2011). Crossed concepts: Habitus and reflexivity in a revised framework. CIES e-Working Paper 113. Sjá https://repositorio.iscte-iul.pt/bitstream/10071/2975/1/CIES-WP113_Conde.pdf

Cucchiara, M. B. og Horvat, E. M. (2013). Choosing selves: the salience of parental identity in the school choice process. Journal of Education Policy, 29(4), 486-509. doi:10.1080/02680939.2013.849760

Devine, F., Savage, M., Scott, J. og Crompton, R. (ritstjórar). (2005). Rethinking class: culture, identities and lifestyles. New York: Palgrave Macmillan.

Dovemark, M., Kosunen, S., Kauko, J., Magnúsdóttir, B., Hansen, P. og Rasmussen, P. (2018). Deregulation, privatisation and marketisation of Nordic comprehensive education: Social changes reflected in schooling. Education Inquiry, 9(1), 122-141. doi:10.1080/20004508.2018.1429768

Dudley-Marling, D., og Baker, D. (2012). The effects of market-based school reforms on students with disabilities. Disability Studies Quarterly, 32(2), 1-19. DOI: http://dx.doi.org/10.18061/dsq.v32i2.3187

Dýrfjörð, K. og Magnúsdóttir, B. R. (2016). Privatization of the early childhood education in Iceland. Research in Comparative and International Education 11(1), 80-97. doi:10.1177/1745499916631062

Gewirtz, S. (2002). The managerial school: postwelfarism and social justice in education. London: Routledge.

Guðbjörg Vilhjálmsdóttir og Guðmundur B. Arnkelsson. (2013). Social aspects of career choice from the perspective of habitus theory. Journal of Vocational Behavior, 83(3), 581-590. doi:10.1016/j.jvb.2013.08.002

Hall, S. (2001). Foucault: Power, knowledge and discourse. Í M. Wetherell, S. Taylor og S. J.Yates (ritstjórar), Discourse theory and practice (bls. 72-81). London, Thousand Oaks, New Delhi: Sage.

Hochschild, J. og Scovronik, N. (2003). The American dream and the public schools. New York: Oxford University Press.

Horvat, E. M., Weininger, E. B. og Lareau, A. (2003). From social ties to social capital: Class differences in the relations between schools and parent networks. American Educational Research Journal, 40(2), 319-351.

Katrín Björg Birgisdóttir og Ingólfur Ásgeir Jóhannesson. (2012). Er hægt að bjóða kynjakerfinu birginn? Reynsla átta kvenna af smíðum og tölvunarfræði. Netla - Veftímarit um uppeldi og menntun. Sótt af http:// netla.hi.is/greinar/2012/ryn/010.pdf

Lareau,A. og Horvat, E. M. (1999). Moments of social inclusion and exclusion race, class, and cultural capital in family-school relationships. Sociology of Education, 72(1), 37-53.

Lindblad, S., Johannesson, I. A. og Simola, H. (2002). Education governance in transition: An introduction. Scandinavian Journal of Educational Research, 46(3), 237-245. doi:10.1080/0031383022000005652

Margrét Einarsdóttir. (2014). Paid work of children and teenagers in Iceland: Participation and protection (óútgefin doktorsritgerð). Háskóli Íslands, Reykjavík.

Posey-Maddox, L., Kimelberg, S. M. og Cucchiara, M. (2014). Seeking a 'critical mass': middle-class parents' collective engagement in city public schooling. British Journal of Sociology of Education, 37(7), 905-927. do i:10.1080/01425692.2014.986564

Power, S., Edwards, T., Whitty, G. og Wigfall, V. (2003). Education and the middle class. Buckingham: Open University Press.

Reay, D. (2005). Beyond Consciousness? The Psychic Landscape of Social Class. Sociology, 39(5), 911-928. doi:10.1177/0038038505058372

Reay, D. (2010). Identity making in schools and classrooms. Í M. Wetherell og C. T. Mohanty (ritstjórar), The Sage Handbook of Identities (bls. 277-294). London: Sage. 
Reay, D., Crozier, G. og James, D. (2011). White middle-class identities and urban schooling. New York: Palgrave. Reay, D., David, M. og Ball, S. J. (2005). Degrees of choice. Sterling: Trentham books.

Savage, M., Warde, A. og Devine, F. (2005). Capitals, assets, and resources: some critical issues. The British Journal of Sociology, 56(1), 31-47. doi:10.1111/j.1468-4446.2005.00045.x

Tilly, C. (1996). Citizenship, identity and social history. Cambridge: Cambridge University Press.

Vincent, C., Ball, S. J. og Braun, A. (2007). 'Local childcare cultures': Working class families and pre-school childcare. Sótt af https://s3-eu-west-1.amazonaws.com/esrc-files/outputs/6kJ17wZ6gUWN1XYSWulMbg/9a8MBKZxNkeW3e9ARIzRog.pdf

Vincent, C., Rollock, N., Ball, S. og Gillborn, D. (2012). Being strategic, being watchful, being determined: Black middle-class parents and schooling. British Journal of Sociology of Education, 33(3), 337-354. doi:10. 1080/01425692.2012.668833

Weininger, E. B. (2005). Foundations of Pierre Bourdieu's class analysis. Í E. O. Wright (ritstjóri), Approaches to class analysis (bls. 82-118). Cambridge: Cambridge University Press.

Wright, E. O. (2005). Foundations of a neo-Marxist class analysis. Í E. O. Wright (ritstjóri), Approaches to class analysis (bls. 4-30). Cambridge: Cambridge University Press.

Yoon, E.-S. (2016). Young people's cartographies of school choice: the urban imaginary and moral panic. Children's Geographies, 14(1), 101-114. doi:10.1080/14733285.2015.1026875

Dorgerður Einarsdóttir og Berglind Rós Magnúsdóttir. (2005). Karlar í útrýmingarhættu? Um stöðu kvenna og karla í framhaldsskólum og háskólum. Í Steinunn Helga Lárusdóttir, Dórdís Dórðardóttir og Arna H. Jónsdóttir (ritstjórar), Kynjamyndir í skólastarfi (bls. 199-219). Reykjavík: Rannsóknarstofnun Kennaraháskóla Íslands.

Dórður Kristinsson. (2005). Upplifun karla af hjúkrunarnámi: Hvað stendur í vegi fyrir auknum hlut karla í hjúkrun? Sótt af http://hdl.handle.net/10802/324

Berglind Rós Magnúsdóttir og Unnur Edda Garðarsdóttir. (2018).

„Bara ekki mínar týpur!“ Sjálfsmyndarsköpun, félagsleg aðgreining og framhaldsskólaval.

Netla - veftímarit um uppeldi og menntun. Sérrit 2018 - Framhaldsskólinn í brennidepli.

Menntavísindasvið Háskóla Íslands.

Sótt af http://netla.hi.is/serrit/2018/framhaldskolinn_brennidepli/13.pdf

DOI: https://doi.org/10.24270/serritnetla.2019.13

1. Nema að pví leyti að margir peirra hafa meira fjármagn til pátttöku í samkeppninni með skólagjöldum og ýmsum sveigjanleika.

2. Sjá http://bil.is/skapandi-greinar-nidurstodur-rannsoknarverkefnis

3. Hér er annars vegar átt við rannsóknina Virkni, val og skyldur foreldra á íslenskum menntavettvangi: Samspil kyns, uppruna og félagsstöðu. Hún hófst árið 2016 og er styrkt af Rannsóknarsjóði Háskóla Íslands, R ANNÍS og Jafnréttissjóði Íslands og hins vegar Framhaldsskólaval í Reykjavík og Helsinki sem er styrkt af Rannsóknarsjóði Háskóla Íslands til priggja ára 2018-2021. Báđar pessar rannsóknir eru leiddar af fyrri höfundi.

4. Greinin er hluti af stærri rannsókn fyrri höfundar sem hefur verið styrkt af Rannsóknarsjóði Háskóla Íslands (2017) og ber heitið Framhaldsskólaval í Reykjavík og Helsinki: Sjálfsmyndarsköpun á opnum markaði. Önnur grein í sérritinu tengist pessari rannsókn (Ásgerður Bergsdóttir og Berglind Rós Magnúsdóttir, í pessu sérriti). Fyrri höfundur próaði kenningalíkan, fræðilegan grunn verkefnisins, rannsóknartækin (spurningalista) og tillögur að pemagreiningu. Annar höfundur kom inn í verkið, fyrst sem afritari og síðar til að greina ítarlegar viðtalsgögnin við nemendur í forritinu Atlas.ti og sem meðhöfundur að pessari grein. Viðtölin við nemendur voru tekin af fyrri höfundi, Auði Magndísi Auðardóttur og Ásgerði Bergsdóttur.

5. $26 \%$ voru með stjörnumerktar einkunnir.

6. Nemendur 1997-árgangsins sem ná að útskrifast á „réttum tíma“ eða 3-4 árum, skoðað eftir skólum. 